\title{
Importance of the Cu oxidation state for the SO2-poisoning of a Cu-SAPO-34 catalyst in the NH3-SCR reaction
}

Hammershøi, Peter S.; Vennestrøm, Peter N. R.; Falsig, Hanne; Jensen, Anker D.; Janssens, Ton V. W.

Published in:

Applied Catalysis B: Environmental

Link to article, DOI:

10.1016/j.apcatb.2018.05.038

Publication date:

2018

Document Version

Peer reviewed version

Link back to DTU Orbit

Citation (APA):

Hammershøi, P. S., Vennestrøm, P. N. R., Falsig, H., Jensen, A. D., \& Janssens, T. V. W. (2018). Importance of the $\mathrm{Cu}$ oxidation state for the $\mathrm{SO}_{2}$-poisoning of a Cu-SAPO-34 catalyst in the $\mathrm{NH}_{2}$-SCR reaction. Applied Catalysis B: Environmental, 236,377-383. https://doi.org/10.1016/j.apcatb.2018.03.038

\section{General rights}

Copyright and moral rights for the publications made accessible in the public portal are retained by the authors and/or other copyright owners and it is a condition of accessing publications that users recognise and abide by the legal requirements associated with these rights.

- Users may download and print one copy of any publication from the public portal for the purpose of private study or research.

- You may not further distribute the material or use it for any profit-making activity or commercial gain

- You may freely distribute the URL identifying the publication in the public portal 


\title{
Importance of the $\mathrm{Cu}$ oxidation state for the $\mathrm{SO}_{2}$-poisoning of a $\mathrm{Cu}$-SAPO-34 catalyst in the $\mathrm{NH}_{3}-\mathrm{SCR}$ reaction
}

\author{
Peter S. Hammershøi ${ }^{\mathrm{a}, \mathrm{b}}$, Peter N. R. Vennestrømª, Hanne Falsig ${ }^{\mathrm{c}}$, Anker D. \\ Jensen $^{\mathrm{b}}$, Ton V. W. Janssens ${ }^{\mathrm{a}, *}$
}

\author{
${ }^{a}$ Umicore Denmark ApS, Nøjsomhedsvej 20, 2800 Kgs. Lyngby, Denmark \\ ${ }^{\mathrm{b}}$ Department of Chemical and Biochemical Engineering, Technical University of Denmark, Søltofts Plads \\ B229, 2800 Kgs. Lyngby, Denmark \\ ${ }^{\mathrm{c}}$ Haldor Topsoe A/S, Haldor Topsøe's Allé 1, 2800 Kgs. Lyngby, Denmark \\ *Corresponding author. Phone: +45 227546 22, e-mail address: tonv.w.janssens@eu.umicore.com
}

\section{Abstract}

$\mathrm{Cu}$-exchanged zeolites of the CHA structure are state-of-the-art catalysts for selective catalytic reduction of $\mathrm{NO}_{\mathrm{x}}$ with $\mathrm{NH}_{3}$ in diesel aftertreatment systems. However, these catalysts deactivate in the presence of $\mathrm{SO}_{2}$, which is a constituent of diesel exhaust gas. In this article, the deactivation behavior and mechanisms of a CuSAPO-34 catalyst were studied with reactor tests and DFT calculations. Exposure of the catalyst to two different $\mathrm{SO}_{2}$ concentrations and durations, but with the same total $\mathrm{SO}_{2}$ exposure, calculated as the product of partial pressure of $\mathrm{SO}_{2}$ and exposure time, lead to the same degree of deactivation. Exposure of the Cu-SAPO34 catalyst to $\mathrm{SO}_{2}$ in the presence and absence of $\mathrm{NO}$ and $\mathrm{NH}_{3}$ at different temperatures between $200-600{ }^{\circ} \mathrm{C}$ showed different trends for the deactivation. Below $400{ }^{\circ} \mathrm{C}$, the $\mathrm{S} / \mathrm{Cu}$ ratio on the catalyst increased with temperature in absence of $\mathrm{NO}$ and $\mathrm{NH}_{3}$, while it decreased with increasing temperature in the presence of $\mathrm{NO}$ and $\mathrm{NH}_{3}$. This is explained by the ability of $\mathrm{NO}$ and $\mathrm{NH}_{3}$ to reduce $\mathrm{Cu}(\mathrm{II})$ to $\mathrm{Cu}(\mathrm{I})$. DFT calculations show that $\mathrm{SO}_{2}$ adsorbs more strongly on $\mathrm{Cu}(\mathrm{I})$ than on $\mathrm{Cu}$ (II). Above $400{ }^{\circ} \mathrm{C}$, the $\mathrm{S} / \mathrm{Cu}$ ratio decreased with temperature irrespective of the presence of $\mathrm{NO}$ and $\mathrm{NH}_{3}$. In all cases, the $\mathrm{S} / \mathrm{Cu}$ ratio is lower than 1 . This is not compatible with extensive deposition of ammonium sulfate when co-feeding $\mathrm{SO}_{2}, \mathrm{H}_{2} \mathrm{O}$ and $\mathrm{NH}_{3}$. A more likely explanation for the deactivation is that $\mathrm{SO}_{2}$ is mainly related to the $\mathrm{Cu}$ sites. This is further corroborated by DFT calculations showing that $\mathrm{SO}_{2}$ and $\mathrm{SO}_{3}$, which is possibly formed by oxidation of $\mathrm{SO}_{2}$ over $\mathrm{Cu}$ sites, interact similar with $\mathrm{Cu}$ in $\mathrm{Cu}-\mathrm{SAPO}-34$ and $\mathrm{Cu}-\mathrm{SSZ}-13$. 


\section{Keywords}

$\mathrm{NH}_{3}-\mathrm{SCR}, \mathrm{SO}_{2}$ poisoning, Deactivation, $\mathrm{Cu}-\mathrm{CHA}$, DFT 


\section{Introduction}

Diesel engines operate with excess air in the combustion, leading to production of nitrogen oxides $\left(\mathrm{NO}_{\mathrm{x}}\right)$. $\mathrm{NO}_{\mathrm{x}}$ emissions from diesel engines are a source of air pollution and are therefore regulated. To meet legislation requirements for $\mathrm{NO}_{\mathrm{x}}$ emissions, a modern aftertreatment systems for diesel engines contain one or more catalysts for the reduction of $\mathrm{NO}_{\mathrm{x}}$ to $\mathrm{N}_{2}$ by selective catalytic reduction with $\mathrm{NH}_{3}\left(\mathrm{NH}_{3}-\mathrm{SCR}\right)$. The $\mathrm{NH}_{3}-\mathrm{SCR}$ proceeds according to the reaction: $4 \mathrm{NH}_{3}+4 \mathrm{NO}+\mathrm{O}_{2} \rightarrow 4 \mathrm{~N}_{2}+6 \mathrm{H}_{2} \mathrm{O}$. Urea injected in the exhaust gas stream is commonly used as a source for $\mathrm{NH}_{3}$, and, if properly controlled, the $\mathrm{NH}_{3}$-SCR reaction can reach very high degrees of $\mathrm{NO}_{\mathrm{x}}$ removal. The currently applied catalysts for $\mathrm{NH}_{3}$-SCR are based on $\mathrm{V}$-oxide, $\mathrm{Fe}$ zeolites or Cu-zeolites.

Current zeolite state-of-the-art $\mathrm{NH}_{3}-\mathrm{SCR}$ catalysts are based on the CHA structure due to its better hydrothermal stability than other commercial zeolite structures [1]. The CHA structure exists with an overall chemical composition of $\mathrm{H}_{\mathrm{n}} \mathrm{Al}_{\mathrm{n}} \mathrm{Si}_{1-\mathrm{n}} \mathrm{O}_{2}$ (SSZ-13) or $\mathrm{H}_{\mathrm{n}} \mathrm{Si}_{\mathrm{n}} \mathrm{AlP}_{1-\mathrm{n}} \mathrm{O}_{4}$ (SAPO-34), under the assumption that only $\mathrm{P}$ is substituted by $\mathrm{Si}$. $\mathrm{Cu}$ ions are introduced into the ion-exchange positions in these materials, and these $\mathrm{Cu}$ sites are the source of the catalytic activity of $\mathrm{Cu}-\mathrm{CHA}$ catalysts. Compared to Fe-zeolites and vanadia-based SCR catalysts, the main advantages of the $\mathrm{Cu}$-CHA catalysts are superior low-temperature SCR activity and lower $\mathrm{N}_{2} \mathrm{O}$ selectivity $[2,3]$. A disadvantage of the $\mathrm{Cu}-\mathrm{CHA}$ catalysts is their susceptibility towards poisoning by $\mathrm{SO}_{2}[4,5] . \mathrm{SO}_{2}$ is an inevitable compound in diesel exhausts, and even at concentration levels below 15 ppm, as in ultra-low sulfur diesel $[4,6]$, the resulting $\mathrm{SO}_{2}$ in the exhaust gas, typically about 1-2 ppmv, has a significant impact on the performance of $\mathrm{Cu}$-CHA catalysts. It is therefore important to understand how $\mathrm{SO}_{2}$ affects the $\mathrm{Cu}-\mathrm{CHA}$ catalysts.

The gas stream that the SCR catalyst is exposed to in a diesel exhaust system consists of several other compounds than $\mathrm{SO}_{2}$, including but not limited to $\mathrm{O}_{2}, \mathrm{H}_{2} \mathrm{O}, \mathrm{NO}$ and $\mathrm{NH}_{3}$. These compounds may affect the interaction of $\mathrm{SO}_{2}$ with the $\mathrm{Cu}$-CHA catalyst. Several $\mathrm{SO}_{2}$-poisoning studies have been carried out in gas compositions where $\mathrm{NO}$ and $\mathrm{NH}_{3}$ are omitted [4-11]. Such experiments have shown that the deactivation is due to $\mathrm{SO}_{2}$ interactions with $\mathrm{Cu}$, which is dependent on the temperature of $\mathrm{SO}_{2}$ exposure. Adsorption of $\mathrm{SO}_{2}$ 
mainly takes place at temperatures around $200{ }^{\circ} \mathrm{C}$ [5], while chemical reactions between $\mathrm{SO}_{2}$ and $\mathrm{Cu}$ become more dominating at temperatures around $400{ }^{\circ} \mathrm{C}[5] . \mathrm{SO}_{2}$ reacts at the $\mathrm{Cu}$ sites in the $\mathrm{CHA}$, resulting in $(\mathrm{Cu}, \mathrm{S})$ species with $\mathrm{S}$ in oxidation state +6 , which are assigned to isolated $\mathrm{Cu}$-sulfates $[4,12]$. This assignment is corroborated by their decomposition temperature of around $650{ }^{\circ} \mathrm{C}$, which is consistent with the decomposition of bulk $\mathrm{CuSO}_{4}[4,11,13]$, and by an observed 1:1 correlation between the $\mathrm{S} / \mathrm{Cu}$ ratio of these species and the deactivation [11]. The formation of sulfates implies that $\mathrm{SO}_{2}$ is oxidized over the catalyst, and the rate of oxidation increases with temperature [10]. The effect of the gas composition on the deactivation by $\mathrm{SO}_{2}$ is not fully understood, and therefore, it is important to improve the understanding in order to be able to transfer results to the $\mathrm{SO}_{2}$-poisoning occurring in real exhausts.

It has been argued that the effect of $\mathrm{NO}$ and $\mathrm{NH}_{3}$ on $\mathrm{SO}_{2}$-poisoning is the formation of ammonium sulfate, which may infer mass transfer limitations by pore-blocking [14-16]. However, ammonium sulfate decomposes at about $350{ }^{\circ} \mathrm{C}$, and can therefore feasibly be removed [16]. Moreover, the presence of $\mathrm{NO}$ and $\mathrm{NH}_{3}$, or release of $\mathrm{NH}_{3}$ from ammonium sulfate, has a suggested beneficial effect on the regeneration of $\mathrm{SO}_{2}$-poisoned catalysts, due to the reducing properties of the SCR gas mixture and $\mathrm{NH}_{3}[8,16]$.

In this article the $\mathrm{SO}_{2}$ deactivation behavior of a Cu-SAPO-34 catalyst was investigated. The Cu-SAPO-34 was chosen because of its high hydrothermal stability so that high-temperature regeneration did not result in deterioration of the zeolite structure; something that cannot always be avoided with SSZ-13. We investigated the effect of $\mathrm{SO}_{2}$ exposure time, $\mathrm{SO}_{2}$ concentration, and the presence of $\mathrm{NO}$ and $\mathrm{NH}_{3}$ on the deactivation by $\mathrm{SO}_{2}$. DFT calculations were used to evaluate the interactions between $\mathrm{Cu}, \mathrm{SO}_{2}$ and $\mathrm{SO}_{3}$ in order to obtain a better understanding of the temperature dependence, and effect of $\mathrm{NO}$ and $\mathrm{NH}_{3}$, on the deactivation.

\section{Experimental}

\subsection{Catalyst material and reactor testing conditions}

A commercial Cu-SAPO-34 catalyst was used for this study. The catalyst has a $(\mathrm{P}+\mathrm{Al}) / \mathrm{Si}$ of 6.5 and a $\mathrm{Cu}-$ loading of $1.9 \mathrm{wt} \%$, as determined by ICP-OES. The steady-state conversions of $\mathrm{NO}$ in the $\mathrm{NH}_{3}-\mathrm{SCR}$ reaction were measured in a fixed-bed quartz reactor with an inner diameter of $2 \mathrm{~mm}$, using $5 \mathrm{mg}$ catalyst on dry matter 
basis, and a sieve fraction of 150-300 $\mu \mathrm{m}$. The SCR-feed gas for the activity measurements consisted of 500 ppmv $\mathrm{NO}, 530$ ppmv $\mathrm{NH}_{3}, 10 \% \mathrm{O}_{2}$ and $5 \% \mathrm{H}_{2} \mathrm{O}$, in $\mathrm{N}_{2}$ at a total flow of $225 \mathrm{NmL} \mathrm{min}^{-1}$. The inlet and outlet gas composition was determined using a Gasmet CX4000 FTIR analyser. Prior to the $\mathrm{NH}_{3}$-SCR activity measurements, the catalyst was heated for $1 \mathrm{~h}$ in the SCR-feed gas at $550{ }^{\circ} \mathrm{C}$. The effect of $\mathrm{SO}_{2}$ on the $\mathrm{NH}_{3^{-}}$ SCR activity was determined from a comparison of the $\mathrm{NO}_{\mathrm{x}}$ conversion before and after exposure of the catalyst to an $\mathrm{SO}_{2}$-containing feed gas in the same reactor setup.

The catalyst was exposed to $\mathrm{SO}_{2}$ in a flow with either SCR-feed gas, or with $10 \% \mathrm{O}_{2}$ and $5 \% \mathrm{H}_{2} \mathrm{O}$, balanced by $\mathrm{N}_{2}$ to a total flow rate of $225 \mathrm{NmL} \mathrm{min}^{-1}$. The inlet concentrations of $\mathrm{SO}_{2}$ were 1.5 or $15 \mathrm{ppmv}$. The temperature and duration of $\mathrm{SO}_{2}$ exposure were varied and are stated specifically with the results.

The evaluation of the $\mathrm{NH}_{3}-\mathrm{SCR}$ activity is based on the rate constant for the $\mathrm{NH}_{3}$-SCR reaction. The rate constants $(k)$ are derived from measured steady state $\mathrm{NO}_{\mathrm{x}}$ conversions, as shown in Eq. (1), assuming plug flow of the gas and that the $\mathrm{NH}_{3}-\mathrm{SCR}$ reaction is first order in NO.

$$
k=-\frac{F}{W} \ln (1-X)
$$

$F$ is the total molar flow rate, $W$ is the total mass of catalyst on a dry matter basis, and $X$ is the $\mathrm{NO}_{\mathrm{x}}$ conversion.

The deactivation of the catalyst is calculated from a comparison of rate constants after $\mathrm{SO}_{2}$ exposure or regeneration with the corresponding rate constant of the fresh catalyst. In this article, we define the deactivation as:

$$
\text { Deactivation }=1-\frac{k}{k_{\text {fresh }}}
$$

\subsection{Computational}

Spin polarized Density Functional Theory (DFT) calculations were used to obtain adsorption energies of $\mathrm{O}_{2}$, $\mathrm{SO}_{2}$ and $\mathrm{SO}_{3}$ on $\mathrm{Cu}$ species in SAPO-34 and SSZ-13. The calculations were performed with the GPAW package $[17,18]$ using a real space grid-based projector augmented wave method. A grid spacing of $h=0.2$ and 
a Fermi smearing of $0.1 \mathrm{~K}$ were found sufficient to obtain a satisfactory convergence of the relative energies.

To account for Van der Waals interactions the BEEF-vdW functional was used [19]. This functional has shown to produce reliable results for the interaction of molecules with zeolites [20,21]. Both SSZ-13 and SAPO-34 were represented by periodic cells with hexagonal symmetry containing 36 T-atoms (SSZ-13 cell parameters: $\mathrm{a}, \mathrm{b}=13.886 \AA, \mathrm{c}=15.116 \AA, \alpha=120^{\circ}, \beta, \gamma=90^{\circ}$ and SAPO-34 cell parameters: $\mathrm{a}, \mathrm{b}=14.602 \AA, \mathrm{c}=15.287$ $\left.\AA, \alpha=120^{\circ}, \beta, \gamma=90^{\circ}\right)$.

\section{Results}

\subsection{Deactivation by $\mathrm{SO}_{2}$ exposure and scalability}

Figure $1 \mathrm{~A}$ shows the measured steady state $\mathrm{NO}_{\mathrm{x}}$ conversions for the fresh catalyst, after exposure to $\mathrm{SO}_{2}$, and after regeneration at $550{ }^{\circ} \mathrm{C}$. For the $\mathrm{SO}_{2}$ exposure, $1.5 \mathrm{ppmv}$ of $\mathrm{SO}_{2}$ was added to the SCR-feed, which is in the $\mathrm{SO}_{2}$ concentration range expected in automotive diesel exhaust, and the catalyst was held at $300{ }^{\circ} \mathrm{C}$ for $8 \mathrm{~h}$. The regeneration of the catalyst was performed at $550{ }^{\circ} \mathrm{C}$ for $1 \mathrm{~h}$ in SCR-feed gas without $\mathrm{SO}_{2}$. Exposure to $\mathrm{SO}_{2}$ leads to significantly lower steady state $\mathrm{NO}_{\mathrm{x}}$ conversions in the temperature range $150-300{ }^{\circ} \mathrm{C}$.

Regeneration at $550{ }^{\circ} \mathrm{C}$ restores most of the original $\mathrm{NO}_{\mathrm{x}}$ conversion in this temperature range. This behavior has also been observed for an aluminosilicate $\mathrm{Cu}$-CHA catalyst, and can be understood in terms of irreversible and reversible deactivation [11]. According to the definitions in [11], the deactivation measured after regeneration at $550{ }^{\circ} \mathrm{C}$ is the irreversible deactivation, and the difference in deactivation after $\mathrm{SO}_{2}$ exposure and regeneration at $550^{\circ} \mathrm{C}$ is the reversible deactivation.

For practical reasons when investigating $\mathrm{SO}_{2}$ deactivation, it is often useful to accelerate the $\mathrm{SO}_{2}$-poisoning by increasing the $\mathrm{SO}_{2}$ concentration and proportionally shortening the exposure time. The results are then interpreted in terms of the total $\mathrm{SO}_{2}$ exposure, calculated as the product of the $\mathrm{SO}_{2}$ partial pressure and the exposure time, rather than the $\mathrm{SO}_{2}$ concentration. This interpretation requires that a direct proportionality exists between the exposure time and $\mathrm{SO}_{2}$ concentration, such that these two parameters can be scaled with respect to $\mathrm{SO}_{2}$-poisoning. This scalability was investigated by comparing the results of the non-accelerated $\mathrm{SO}_{2}$ exposure, i.e. exposure to $1.5 \mathrm{ppmv} \mathrm{SO}_{2}$, to the results from a catalyst exposed to an accelerated $\mathrm{SO}_{2}$ 
exposure. For the accelerated $\mathrm{SO}_{2}$ exposure, the $\mathrm{SO}_{2}$ concentration was increased by a factor 10 and the exposure time was correspondingly decreased, thus exposing to $15 \mathrm{ppmv} \mathrm{SO}_{2}$ in $\mathrm{SCR}$-feed gas for $48 \mathrm{~min}$ at $300{ }^{\circ} \mathrm{C}$. The steady state $\mathrm{NO}_{\mathrm{x}}$ conversions before and after the accelerated $\mathrm{SO}_{2}$ exposure, and after $1 \mathrm{~h}$ regeneration at $550^{\circ} \mathrm{C}$ in SCR-feed gas, are plotted in Figure 1B.

The appearance of the $\mathrm{NO}_{x}$ conversion curve for the accelerated $\mathrm{SO}_{2}$ exposed catalyst in Figure $1 \mathrm{~B}$, is very similar to that shown in Figure 1A. The $\mathrm{NO}_{\mathrm{x}}$ conversions of the fresh catalyst shown in Figure 1B are slightly lower than those of the fresh catalyst in Figure 1A, which is due to small differences in the catalyst loads. Therefore, in order to further confirm the similarity of the impact of the accelerated and non-accelerated $\mathrm{SO}_{2}$ exposure conditions on the SCR performance of the catalyst, the deactivation (evaluated at $180{ }^{\circ} \mathrm{C}$ ) after $\mathrm{SO}_{2}$ exposure and regeneration are plotted in Figure 1C. The degree of deactivation after both treatments are similar, with total deactivations of 80 and $79 \%$ and irreversible deactivations of 16 and $18 \%$. This means that the deactivation is the same for the same total $\mathrm{SO}_{2}$ exposure, and indicates that the $\mathrm{SO}_{2}$ concentration and exposure time are scalable.

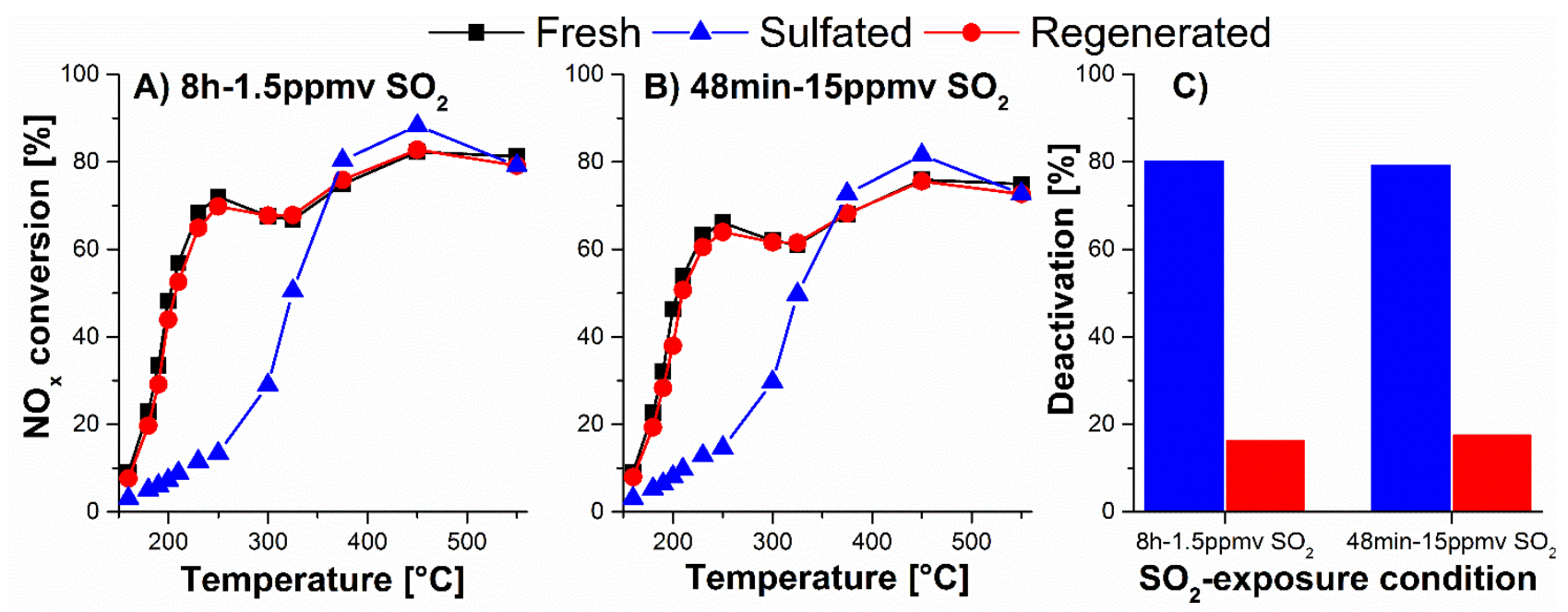

Figure $1-A) \mathrm{NO}_{x}$ conversion as function of temperature for the Cu-SAPO-34 catalyst before and after exposure to $1.5 \mathrm{ppmv}^{\mathrm{SO}} \mathrm{f}_{2}$ for 8 h at $300{ }^{\circ} \mathrm{C}$, and after $1 \mathrm{~h}$ regeneration at $\left.550{ }^{\circ} \mathrm{C} . \mathrm{B}\right) \mathrm{NO}$ x conversion as function of temperature for the Cu-SAPO-34 catalyst before and after exposure to $15 \mathrm{ppmv} \mathrm{SO}_{2}$ for $48 \mathrm{~min}$ at $300{ }^{\circ} \mathrm{C}$, and after $1 \mathrm{~h}$ regeneration at $550{ }^{\circ} \mathrm{C}$. Gas flow conditions for $\mathrm{NO} \mathrm{O}_{x}$ measurements and regenerations were 500 ppmv $\mathrm{NO}, 530 \mathrm{ppmv} \mathrm{NH}_{3}, 10 \% \mathrm{O}$, and $5 \% \mathrm{H}_{2} \mathrm{O}$ in $\mathrm{N}_{2}$ at $225 \mathrm{NmL} / \mathrm{min}$. The same gas flow 
conditions, with addition of $\mathrm{SO}_{2}$, were used for $\mathrm{SO}_{2}$ exposures. C) Deactivation of the sulfated (blue bars) and regenerated (red bars) states of the Cu-SAPO-34 catalyst evaluated at $180^{\circ} \mathrm{C}$, after exposure to $1.5 \mathrm{ppmv} \mathrm{SO}_{2}$ for $8 \mathrm{~h}$ and $15 \mathrm{ppmv}^{\mathrm{SO}} \mathrm{for}_{4}$ f min.

\subsection{Regeneration of the irreversible deactivation}

A possible explanation for the irreversible deactivation is the formation of $\mathrm{Cu}$-sulfates that are stable up to $\sim 650{ }^{\circ} \mathrm{C}[4,11,13]$. If this is true, a full restoration of the activity of the catalyst by heating to $700{ }^{\circ} \mathrm{C}$ should be possible. This was verified by measuring the SCR activity over the Cu-SAPO-34 catalyst after $\mathrm{SO}_{2}$ exposure and again after regeneration at $550{ }^{\circ} \mathrm{C}$ and $700{ }^{\circ} \mathrm{C}$. Figure 2 shows that at $180{ }^{\circ} \mathrm{C}$, the $\mathrm{SCR}$ reaction rate constant is lowest for the sulfated state of the catalyst, and that regeneration first at $550{ }^{\circ} \mathrm{C}$, partially restores the activity, while subsequent regeneration at $700{ }^{\circ} \mathrm{C}$ restores the activity to the original level of the fresh catalyst. This result is consistent with $\mathrm{Cu}$-sulfate species causing the irreversible deactivation, since heating to $700{ }^{\circ} \mathrm{C}$, which is above the decomposition temperature of $\mathrm{CuSO}_{4}$, restores the activity of the catalyst completely.

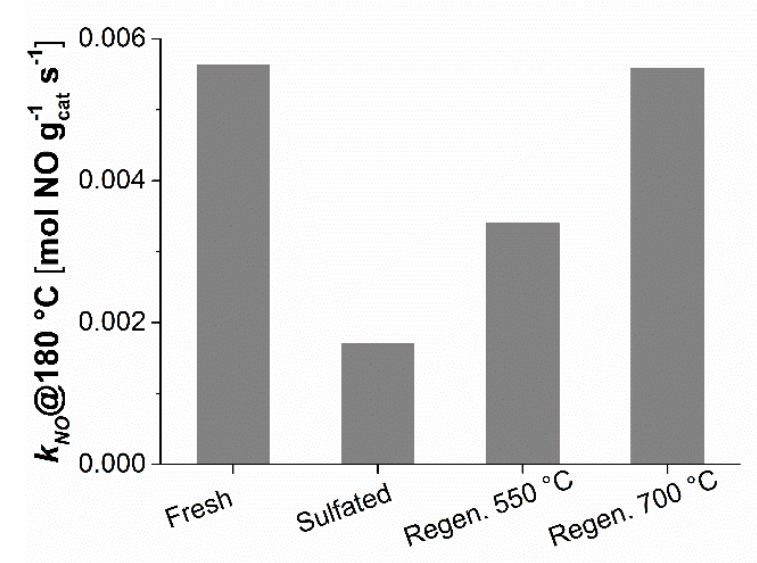

State of the catalyst

Figure 2 - The $\mathrm{NH}_{3}$-SCR rate constants of the different states of the $\mathrm{Cu}$-SAPO-34 catalyst, i.e. fresh, sulfated, regenerated at $550{ }^{\circ} \mathrm{C}$, and regenerated at $700{ }^{\circ} \mathrm{C}$. Sulfation was 24 h at $550{ }^{\circ} \mathrm{C}$ in $15 \mathrm{ppmv} \mathrm{SO}_{2}, 500 \mathrm{ppmv} \mathrm{NO}, 530 \mathrm{ppmv} \mathrm{NH}_{3}, 10 \% \mathrm{O}_{2}$, and $5 \% \mathrm{H}_{2} \mathrm{O}$ in $\mathrm{N}_{2}$ at $225 \mathrm{NmL} / \mathrm{min}$. The regenerations were $1 \mathrm{~h}$ at $550^{\circ} \mathrm{C}$ and $2 \mathrm{~h}$ at $700{ }^{\circ} \mathrm{C}$, and were carried out with the same flow conditions as the sulfation, but in absence of $\mathrm{SO}_{2}$. 


\section{3. $\mathrm{SO}_{2}$ exposure in presence of $\mathrm{NO}$ and $\mathrm{NH}_{3}$}

The SCR catalyst in a diesel exhaust system is exposed to a wide range of temperatures up to approx. $550{ }^{\circ} \mathrm{C}$, with typical operating temperatures between $200-500{ }^{\circ} \mathrm{C}$. Therefore, the impact of temperature on the deactivation was investigated by exposing the Cu-SAPO-34 catalyst to 1.5 ppmv $\mathrm{SO}_{2}$ for $8 \mathrm{~h}$ in the presence of SCR-feed gas at $200,300,400$ and $500{ }^{\circ} \mathrm{C}$. The measured steady state $\mathrm{NO}_{\mathrm{x}}$ conversions are shown in Figure 3A-D before and after $\mathrm{SO}_{2}$ exposure, and after $1 \mathrm{~h}$ of regeneration at $550{ }^{\circ} \mathrm{C}$ in $\mathrm{SCR}$-feed gas. The $\mathrm{NO}_{\mathrm{x}}$ conversion below $325{ }^{\circ} \mathrm{C}$ is lower than for the fresh catalyst in all measurements, for both the sulfated and regenerated states of the catalyst. Furthermore, the deactivations in Figure 4B show that there is a clear trend of more extensive deactivation of the sulfated state of the catalyst at lower $\mathrm{SO}_{2}$ exposure temperature. The $\mathrm{S} / \mathrm{Cu}$ ratios of the catalyst shown in Figure 4A, which were estimated by integration of the measured decrease in $\mathrm{SO}_{2}$ concentrations in the outlet of the reactor during $\mathrm{SO}_{2}$ exposure, also increase at lower $\mathrm{SO}_{2}$ exposure temperature. This is consistent with an interpretation that larger S-uptakes lead to more pronounced deactivation. A different trend is observed for the deactivation of the regenerated states of the catalyst, where only the catalyst exposed to $\mathrm{SO}_{2}$ at $200{ }^{\circ} \mathrm{C}$ stands out with a significantly larger deactivation than the rest. 


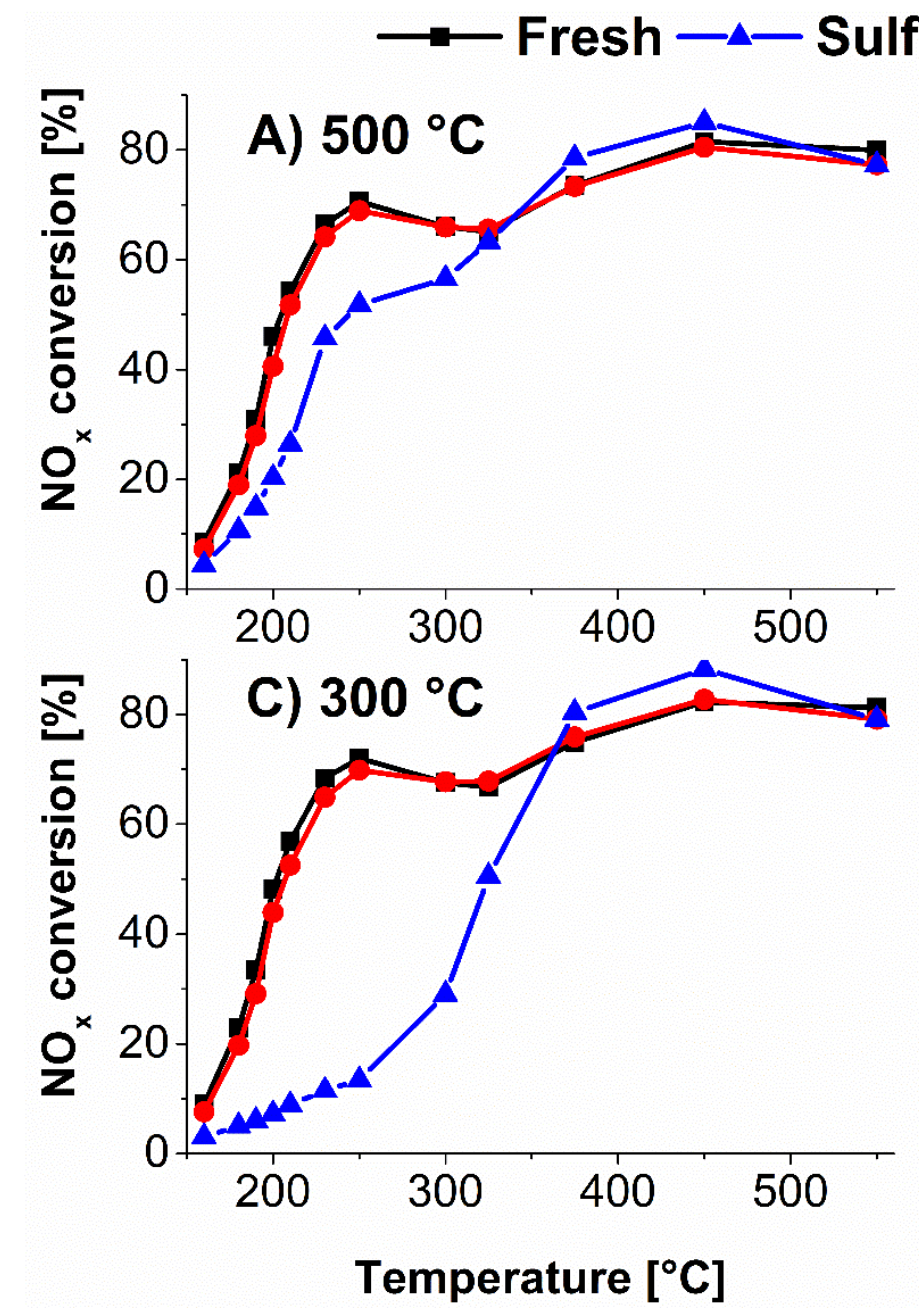

fated $\longrightarrow$ Regenerated
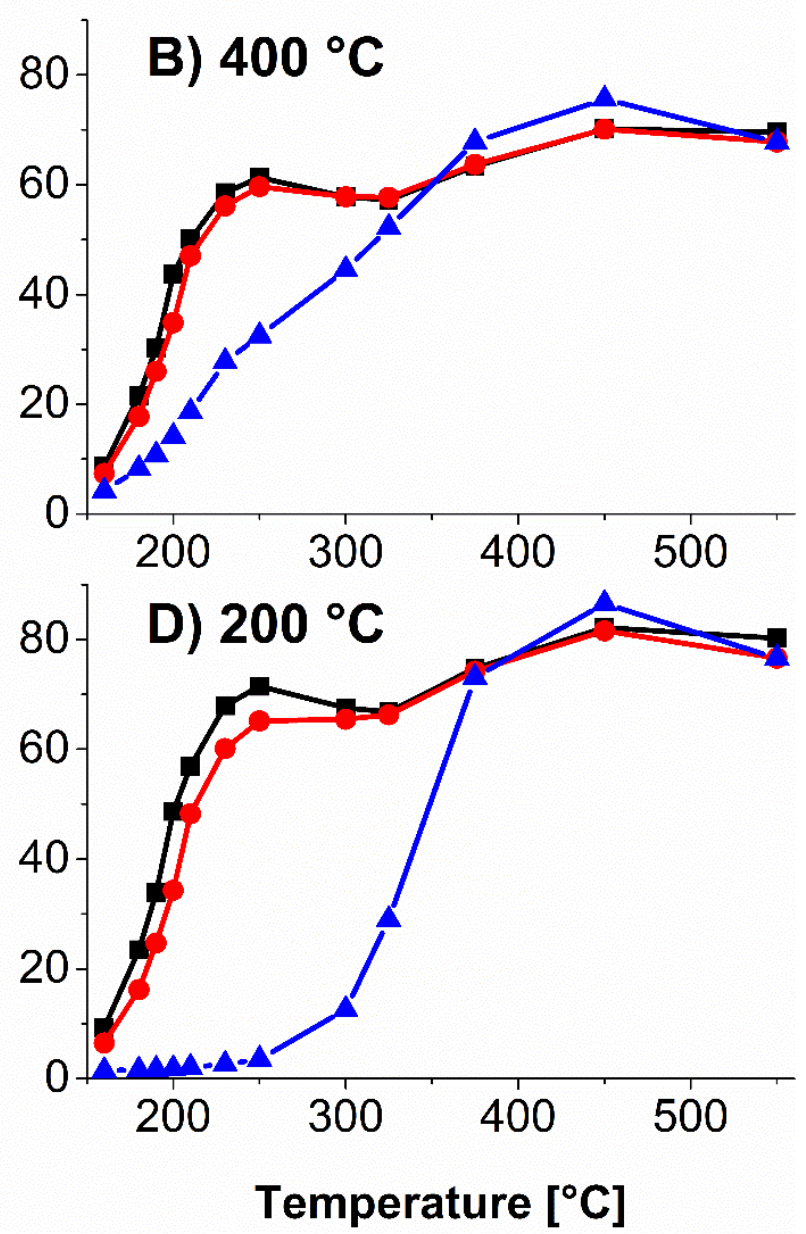

Figure $3-\mathrm{NO}_{x}$ conversions as functions of temperature for the Cu-SAPO-34 catalyst before and after $\mathrm{SO}_{2}$ exposure for $8 \mathrm{~h}$ at A) 500 $\left.{ }^{\circ} \mathrm{C}, \mathrm{B}\right) 400^{\circ} \mathrm{C}$, C) $300^{\circ} \mathrm{C}$, and $\left.\mathrm{D}\right) 200^{\circ} \mathrm{C}$, and after $1 \mathrm{~h}$ regeneration at $550^{\circ} \mathrm{C}$. NO conversion measurements and regenerations were carried out in $500 \mathrm{ppmv} \mathrm{NO}, 530 \mathrm{ppmv} \mathrm{NH}_{3}, 10 \% \mathrm{O}_{2}$, and $5 \% \mathrm{H}_{2} \mathrm{O}$ in $\mathrm{N}_{2}$ at $225 \mathrm{NmL} / \mathrm{min}$, and the same for the $\mathrm{SO}_{2}$ exposures, but with the addition of $1.5 \mathrm{ppmv}^{\mathrm{SO}}$. 


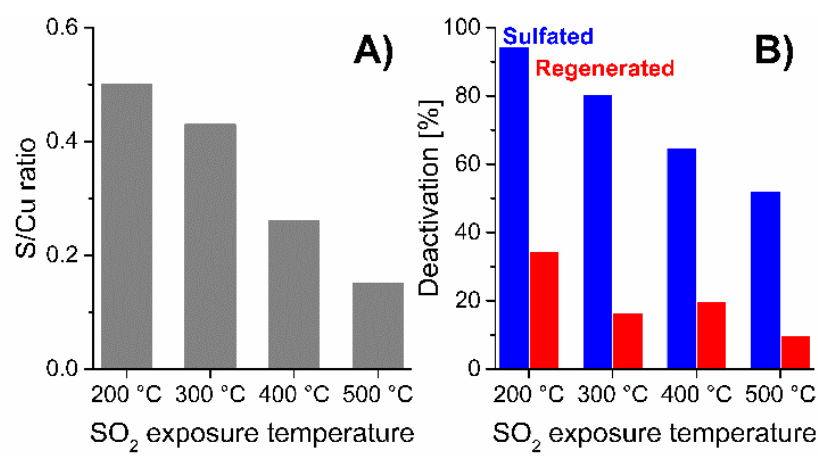

Figure $4-\mathrm{A}) \mathrm{S} / \mathrm{Cu}$ ratios for each $\mathrm{SO}_{2}$ exposure temperature of the Cu-SAPO-34 catalyst after exposure to $1.5 \mathrm{ppmv} \mathrm{SO}_{2}$ in $\mathrm{SCR}_{\text {-feed }}$ gas for 8 h. B) Deactivation evaluated at $180^{\circ} \mathrm{C}$ of the sulfated (blue bars) and regenerated (red bars) states of the Cu-SAPO-34 catalyst for each $\mathrm{SO}_{2}$ exposure temperature with $1.5 \mathrm{ppmv} \mathrm{SO}_{2}$ in $\mathrm{SCR}$-feed gas for $8 \mathrm{~h}$.

In order to see if there is a significant impact of $\mathrm{NO}$ and $\mathrm{NH}_{3}$ presence on the uptake of $\mathrm{SO}_{2}$, the $\mathrm{S}$-uptakes were measured after $\mathrm{SO}_{2}$ exposure in absence of $\mathrm{NO}$ and $\mathrm{NH}_{3}$ as well. This was done in a separate experiment by measuring the $\mathrm{SO}_{2}$ desorption during heating to $700{ }^{\circ} \mathrm{C}$ after $3 \mathrm{~h}$ exposure to $15 \mathrm{ppmv} \mathrm{SO}_{2}$ in $10 \% \mathrm{O}_{2}$ and 5 $\% \mathrm{H}_{2} \mathrm{O}$ at $200-600{ }^{\circ} \mathrm{C}$. This is possible because all $\mathrm{S}$ species desorb as $\mathrm{SO}_{2}[4,13]$, and the complete restoration of the activity by heating to $700{ }^{\circ} \mathrm{C}$ indicates that no sulfur is left on the catalyst (see Figure 2) [11]. The area of the $\mathrm{SO}_{2}$ desorption peaks in Figure 5 reveal that there is a maximum S-uptake at $400{ }^{\circ} \mathrm{C}$, after $\mathrm{SO}_{2}$ exposure in absence of $\mathrm{NO}$ and $\mathrm{NH}_{3}$, which is different from the $\mathrm{SO}_{2}$ exposure in the presence of $\mathrm{NO}$ and $\mathrm{NH}_{3}$.

A comparison of the $\mathrm{SO}_{2}$ uptake at different temperatures in the presence and absence of $\mathrm{NO}$ and $\mathrm{NH}_{3}$ is shown in Figure 6. Since the $\mathrm{SO}_{2}$ exposure conditions of the two series are different, the absolute $\mathrm{S} / \mathrm{Cu}$ ratios are not directly comparable, but the trends with respect to the exposure temperature are. In the presence of NO and $\mathrm{NH}_{3}$, the $\mathrm{S} / \mathrm{Cu}$ ratio decreases monotonically at increased temperature, whereas a maximum for the $\mathrm{S} / \mathrm{Cu}$ ratio is observed at $400{ }^{\circ} \mathrm{C}$ in the absence of $\mathrm{NO}$ and $\mathrm{NH}_{3}$. A possible explanation for the different trends below $400{ }^{\circ} \mathrm{C}$ is the deposition of ammonium sulfates in the zeolite pores at low temperatures, which decompose above $350{ }^{\circ} \mathrm{C}$ to restore catalytic activity [14-16]. Interestingly, the trends of the $\mathrm{S} / \mathrm{Cu}$ ratios in the presence and absence of $\mathrm{NO}$ and $\mathrm{NH}_{3}$ appear similar above $400{ }^{\circ} \mathrm{C}$. These results indicate that above $400{ }^{\circ} \mathrm{C}$, the $\mathrm{SO}_{2}$ exposure conditions are similar despite the different inlet gas compositions. This may be rationalized by the faster SCR reaction rate at higher temperatures, where $\mathrm{NO}$ and $\mathrm{NH}_{3}$ are converted to $\mathrm{N}_{2}$ and $\mathrm{H}_{2} \mathrm{O}$ faster, 
which means that increasing parts of the catalyst bed are effectively exposed to $\mathrm{SO}_{2}$ in absence of $\mathrm{NO}$ and $\mathrm{NH}_{3}$ at higher temperatures.

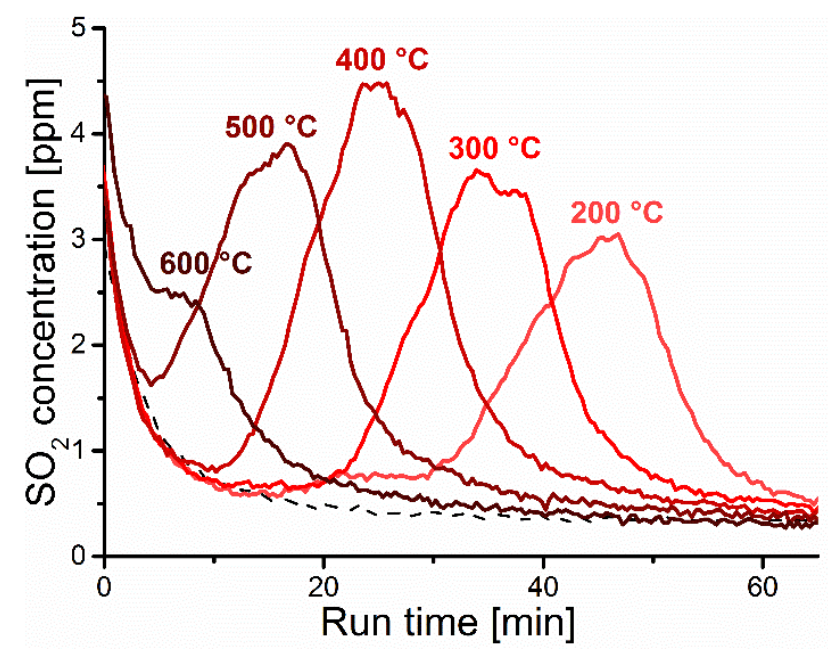

Figure 5 - Outlet $\mathrm{SO}_{2}$ concentrations during heating to $700{ }^{\circ} \mathrm{C}$ after exposing the Cu-SAPO-34 catalyst for $3 \mathrm{~h}$ to $15 \mathrm{ppmv} \mathrm{SO}_{2}$, $10 \%$ $\mathrm{O}_{2}$, and $5 \% \mathrm{H}_{2} \mathrm{O}$ in $\mathrm{N}_{2}$ at $225 \mathrm{NmL} / \mathrm{min}$ and at $200-600{ }^{\circ} \mathrm{C}$. The dashed line is the zero-desorption line.

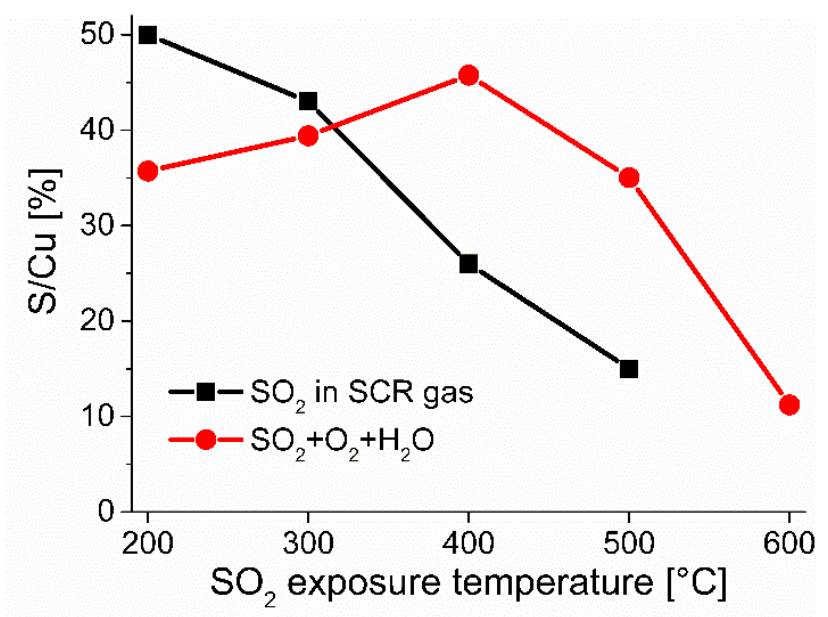

Figure 6 - The $\mathrm{S} / \mathrm{Cu}$ ratios as functions of the $\mathrm{SO}_{2}$ exposure temperature for the $\mathrm{SO}_{2}$ exposures of the Cu-SAPO-34 catalyst in presence and absence of $\mathrm{NO}$ and $\mathrm{NH}_{3}$.

\subsection{Stability of reaction products of $\mathrm{Cu}$ sites with $\mathrm{SO}_{2}$ and $\mathrm{SO}_{3}$}

DFT calculations have been carried out to obtain information about the stability of possible $\mathrm{SO}_{\mathrm{x}}$ species that can be formed in reactions between different $\mathrm{Cu}$ sites in the $\mathrm{Cu}-\mathrm{SAPO}-34$ catalyst and $\mathrm{SO}_{2}$. Because we cannot exclude the formation of some $\mathrm{SO}_{3}$ when exposing to $\mathrm{SO}_{2}$ only, especially at higher temperatures, reactions 
between $\mathrm{Cu}$ sites and $\mathrm{SO}_{3}$ have also been considered in the calculations. The $\mathrm{Cu}$ species that are present in the catalyst is determined by the conditions of the $\mathrm{SO}_{2}$ exposure. In presence of $\mathrm{NO}$ and $\mathrm{NH}_{3}, \mathrm{Cu}$ (II) can reduce to $\mathrm{Cu}(\mathrm{I})$ [22-26], which is modelled as a naked $\mathrm{Cu}(\mathrm{I})$ atom charge-balancing a single exchange site, $\mathrm{Z}-\mathrm{Cu}(\mathrm{I})$. In presence of $\mathrm{O}_{2}$ and $\mathrm{H}_{2} \mathrm{O}$, only $\mathrm{Cu}(\mathrm{II})$ is expected to be present, which can be in two different forms. Either as a single $\mathrm{Cu}(\mathrm{II})$ atom charge-balancing two exchange sites, $\mathrm{Z}_{2}-\mathrm{Cu}(\mathrm{II})$, or as a $\mathrm{Cu}(\mathrm{II})$ atom with a hydroxide ion charge-balancing a single exchange site, $\mathrm{Z}-\mathrm{Cu}(\mathrm{II}) \mathrm{OH}$. The most stable reaction products from reactions between the three different $\mathrm{Cu}$ sites with $\mathrm{SO}_{2}$ or $\mathrm{SO}_{3}$, as determined from DFT calculations, are listed in Table 1.

The DFT calculations show that both $\mathrm{SO}_{2}$ and $\mathrm{SO}_{3}$ are able to form stable species with $\mathrm{Z}-\mathrm{Cu}(\mathrm{II}) \mathrm{OH}$ and with $\mathrm{Z}-\mathrm{Cu}(\mathrm{I})$, in agreement with previous DFT calulations [12]. The calculated change in energy for adsorption of $\mathrm{SO}_{2}, \mathrm{SO}_{3}$ and $\mathrm{O}_{2}$ on $\mathrm{Z}_{2}-\mathrm{Cu}(\mathrm{II})$ is positive, indicating that neither of these species adsorb on the $\mathrm{Z}_{2}-\mathrm{Cu}$ (II) sites. Interestingly, the most stable reaction product of the $\mathrm{Z}-\mathrm{Cu}(\mathrm{I})$ site is in reaction with $\mathrm{SO}_{2}$, while the $\mathrm{Z}-\mathrm{Cu}(\mathrm{II}) \mathrm{OH}$ site forms the most stable species in reaction with $\mathrm{SO}_{3}$. Figure 7 shows the calculated structures of the resulting $\mathrm{Cu}$ species. DFT calculations also indicate that neither $\mathrm{SO}_{2}$ nor $\mathrm{SO}_{3}$ bind to the mobile $\left[\mathrm{Cu}\left(\mathrm{NH}_{3}\right)_{2}\right]^{+}$species, which provides the active centers for $\mathrm{NH}_{3}$-SCR at low temperatures $[27,28]$.

The same calculations of reaction products of $\mathrm{Cu}$ sites with $\mathrm{SO}_{2}$ and $\mathrm{SO}_{3}$ have also been carried out for an aluminosilicate CHA framework, and the results are similar to those for the silicoaluminophosphate Cu-SAPO34 structure, but with a tendency to slightly less stable reaction products. This indicates that the deactivation of $\mathrm{Cu}-\mathrm{CHA}$ catalysts by $\mathrm{SO}_{2}$ and $\mathrm{SO}_{3}$ is mainly related to the $\mathrm{Cu}-\mathrm{SO}_{x}$ chemistry, and that the framework chemistry, therefore, is of lesser importance. 
Table 1 -The stabilities ( $\triangle E$ ) of most stable reaction products from reactions of three different $\mathrm{Cu}$ sites in Cu-SAPO-34 or Cu-SSZ-13 with either $\mathrm{SO}_{2}$ or $\mathrm{SO}_{3}$. ${ }^{*} \mathrm{O}_{2}$ does not adsorb on $\mathrm{Z}_{2}-\mathrm{Cu}(\mathrm{II})$ in neither $\mathrm{Cu}$-SAPO-34 nor in Cu-SSZ-13. Adsorption energies and standard deviations have been obtained from DFT using BEEF-vdW.

\begin{tabular}{|c|c|c|c|c|c|c|}
\hline Cu site & $+\mathrm{SO}_{2} \rightarrow$ & $\begin{array}{l}\mathrm{E}[\mathrm{eV}] \\
\text { Cu-SAPO-34 }\end{array}$ & $\begin{array}{l}\Delta \mathrm{E}[\mathrm{eV}] \\
\text { Cu-SSZ-13 }\end{array}$ & $+\mathrm{SO}_{3} \rightarrow$ & $\begin{array}{l}\Delta \mathrm{E}[\mathrm{eV}] \\
\text { Cu-SAPO-34 }\end{array}$ & $\begin{array}{l}\Delta \mathrm{E}[\mathrm{eV}] \\
\text { Cu-SSZ-13 }\end{array}$ \\
\hline $\mathrm{Z}-\mathrm{Cu}(\mathrm{I})$ & $\mathrm{Z}-\mathrm{Cu}(\mathrm{I})-\mathrm{SO}_{2}(a d s)$ & $\begin{array}{l}-1.07 \\
(+/-0.44)\end{array}$ & $\begin{array}{l}-1.12 \\
(+/-0.48)\end{array}$ & $\mathrm{Z}-\mathrm{Cu}(\mathrm{I})-\mathrm{SO}_{3}(a d s)$ & $\begin{array}{l}-0.80 \\
(+/-0.55)\end{array}$ & $\begin{array}{l}-0.89 \\
(+/-0.55)\end{array}$ \\
\hline $\mathrm{Z}-\mathrm{Cu}(\mathrm{II}) \mathrm{OH}$ & $\mathrm{Z}-\mathrm{Cu}(\mathrm{II}) \mathrm{HSO}_{3}$ & $\begin{array}{l}-0.84 \\
(+/-0.36)\end{array}$ & $\begin{array}{l}-0.73 \\
(+/-0.29)\end{array}$ & $\mathrm{Z}-\mathrm{Cu}(\mathrm{II}) \mathrm{HSO}_{4}$ & $\begin{array}{l}-1.80 \\
(+/-0.36)\end{array}$ & $\begin{array}{l}-1.81 \\
(+/-0.32)\end{array}$ \\
\hline $\mathrm{Z}_{2}-\mathrm{Cu}(\mathrm{II})^{*}$ & $8 \pi$ & $\mathrm{d} \mathrm{SO}_{3}$ do no & orb on thi & in neither $\mathrm{Cu}$-SA & $\mathrm{Cu}$ & -13 \\
\hline
\end{tabular}

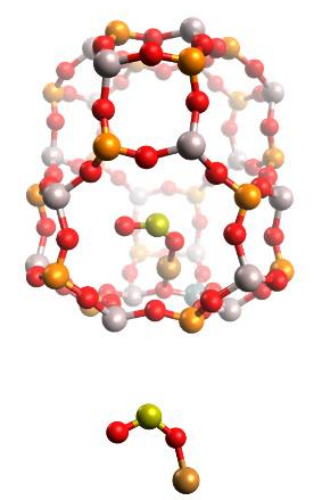

$\mathrm{SO}_{2} / \mathrm{Z}-\mathrm{Cu}(\mathrm{I})$

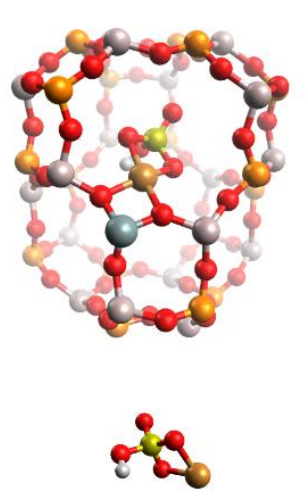

$\mathrm{SO}_{3} / \mathrm{Z}-\mathrm{Cu}(\mathrm{II}) \mathrm{OH}$

Figure 7 - Calculated structures of $\mathrm{SO}_{2}$ adsorbed on $\mathrm{Z}-\mathrm{Cu}(\mathrm{I})$ and $\mathrm{SO}_{3}$ on $\mathrm{Z}-\mathrm{Cu}(\mathrm{II}) \mathrm{OH}$ on $\mathrm{Cu}-\mathrm{SAPO}-34$. The atoms are indicated as follows: $O$ (red), $P$ (orange), Al (light purple), Si (grey), Cu (brown), S (yellow), H (white).

\section{Discussion}

It appears that the deactivation level by $\mathrm{SO}_{2}$ correlates to the total amount of $\mathrm{SO}_{2}$ that the catalyst is exposed to, as shown in Figure 1, where the catalyst has been exposed to different $\mathrm{SO}_{2}$ concentrations and durations at $300{ }^{\circ} \mathrm{C}$. However, this result could also be due to a saturation effect. If a $\mathrm{SO}_{\mathrm{x}}$ saturation level is reached, it means that the S-uptake cannot get larger. In Figure 6 all the $\mathrm{S} / \mathrm{Cu}$ ratios are plotted as functions of the $\mathrm{SO}_{2}$ 
exposure temperature, and the $\mathrm{S}$-uptakes at $200{ }^{\circ} \mathrm{C}$ in presence of $\mathrm{NO}$ and $\mathrm{NH}_{3}$, and at $400{ }^{\circ} \mathrm{C}$ in only $\mathrm{O}_{2}$ and $\mathrm{H}_{2} \mathrm{O}$, are both larger than that at $300{ }^{\circ} \mathrm{C}$ in presence of $\mathrm{NO}$ and $\mathrm{NH}_{3}$. This shows that larger S-uptakes can be reached at higher and lower temperatures, and, therefore, the catalyst exposed to $\mathrm{SO}_{2}$ at $300{ }^{\circ} \mathrm{C}$ in presence of $\mathrm{NO}$ and $\mathrm{NH}_{3}$ is not saturated, which validates the interpretation that the deactivation by $\mathrm{SO}_{2}$ is determined by the total exposure to $\mathrm{SO}_{2}$.

The data in Figure 6 show that exposure to $\mathrm{SO}_{2}$ at $200-600{ }^{\circ} \mathrm{C}$ results in different amounts of S-uptake by the $\mathrm{Cu}-\mathrm{SAPO}-34$ catalyst, dependent on the presence of $\mathrm{NO}$ and $\mathrm{NH}_{3}$. These differences can be related to the different amounts of $\mathrm{Cu}(\mathrm{I})$ and $\mathrm{Cu}(\mathrm{II})$ and the formation of $\mathrm{SO}_{3}$. The DFT calculations presented in Table 1 show, that $\mathrm{SO}_{2}$ adsorbs more strongly than $\mathrm{SO}_{3}$ on $\mathrm{Z}-\mathrm{Cu}(\mathrm{I})$ sites. Since a mixture of $\mathrm{NO}$ and $\mathrm{NH}_{3}$ has reducing properties [22-26], the presence of $\mathrm{NO}$ and $\mathrm{NH}_{3}$ leads to a larger fraction of $\mathrm{Z}-\mathrm{Cu}(\mathrm{I})$ species. This leads to an enhanced driving force for $\mathrm{SO}_{2}$ adsorption on $\mathrm{Cu}$ in the presence of $\mathrm{NO}$ and $\mathrm{NH}_{3}$. The fraction of $\mathrm{Z}-\mathrm{Cu}(\mathrm{I})$ species decreases with increasing temperature, as a faster SCR reaction leads to lower partial pressures of NO and $\mathrm{NH}_{3}$ and faster re-oxidation of the $\mathrm{Cu}$, and therefore the $\mathrm{SO}_{2}$ uptake decreases with increasing temperature in the presence of $\mathrm{NO}$ and $\mathrm{NH}_{3}$, as shown in Figure 6.

In the absence of $\mathrm{NO}$ and $\mathrm{NH}_{3}$, more $\mathrm{Cu}$ is present as $\mathrm{Cu}$ (II) species, and therefore, the adsorption of $\mathrm{SO}_{2}$ on $\mathrm{Cu}(\mathrm{I})$ becomes less important. The DFT calculations show that the $\mathrm{Z}-\mathrm{Cu}(\mathrm{II}) \mathrm{OH}$ site forms the most stable $\mathrm{CuSO}_{\mathrm{x}}$ species in reaction with $\mathrm{SO}_{3}$, while neither $\mathrm{SO}_{2}$ nor $\mathrm{SO}_{3}$ adsorb on the $\mathrm{Z}_{2}-\mathrm{Cu}$ (II) sites. Due to the larger amount of $\mathrm{Cu}(\mathrm{II})$, the $\mathrm{SO}_{2}$ uptake is now determined by the formation of $\mathrm{SO}_{3}$, which then reacts with the $\mathrm{Z}$ $\mathrm{Cu}(\mathrm{II}) \mathrm{OH}$ sites. The increasing $\mathrm{SO}_{2}$ uptake with temperature in the range $200-400{ }^{\circ} \mathrm{C}$ is then a consequence of the increased rate of $\mathrm{SO}_{2}$ oxidation [10]. Above $400{ }^{\circ} \mathrm{C}$, decomposition and desorption of the $\mathrm{CuSO}_{\mathrm{x}}$ species takes place [11], resulting in the lower $\mathrm{SO}_{2}$ uptake with increasing temperature.

It is noted that both in the presence and in the absence of $\mathrm{NO}$ and $\mathrm{NH}_{3}$, the adsorption of $\mathrm{SO}_{2}$ or $\mathrm{SO}_{3}$ always occurs on $\mathrm{Cu}$ sites. Therefore, the total $\mathrm{SO}_{2}$ uptake is limited by the $\mathrm{Cu}$ content, in agreement with the observation that the $\mathrm{S} / \mathrm{Cu}$ ratio does not exceed 1 , despite excessive exposure to $\mathrm{SO}_{2}$ (total exposure of $\mathrm{SO}_{2} / \mathrm{Cu}$ is at least 4.8). It has been argued that deposition of ammonium sulfate in the zeolite pores is the cause of 
deactivation of $\mathrm{Cu}-\mathrm{CHA}$ catalysts [14-16]. This explanation would be consistent with a larger S-uptake in presence of $\mathrm{NO}$ and $\mathrm{NH}_{3}$ below $400{ }^{\circ} \mathrm{C}$, since ammonium sulfate decomposes at around $350{ }^{\circ} \mathrm{C}$ [16]. However, if ammonium sulfate is formed, it is also expected that the amount of sulfur deposited in the catalyst is not limited by the $\mathrm{Cu}$ content. Since the $\mathrm{S}$-uptake is limited by the $\mathrm{Cu}$ content, formation of ammonium sulfate does not seem to be the cause of the larger $\mathrm{SO}_{2}$ uptake and deactivation in the low temperature range in the presence of $\mathrm{NO}$ and $\mathrm{NH}_{3}$.

Finally, the chemical nature of the CHA framework (silicoaluminophosphate or aluminosilicate) seems not to have a significant influence on the deactivation by $\mathrm{SO}_{2}$. As argued in the previous section, the deactivation of the silicoaluminophosphate $\mathrm{Cu}-\mathrm{SAPO}-34$ catalyst by $\mathrm{SO}_{2}$ is related to the chemistry of $\mathrm{Cu}, \mathrm{SO}_{2}$ and $\mathrm{SO}_{3}$, and therefore, $\mathrm{SO}_{2}$-poisoning of the two versions of the $\mathrm{Cu}$-CHA catalysts should be comparable. The response of the $\mathrm{Cu}-\mathrm{SAPO}-34$ catalyst to $\mathrm{SO}_{2}$ exposure and regeneration at $550{ }^{\circ} \mathrm{C}$ in Figure 1, is very similar to that observed on a similar aluminosilicate $\mathrm{Cu}$-CHA catalyst [11]. Furthermore, the results from the DFT calculations in Table 1, show that the $\mathrm{CuSO}_{\mathrm{x}}$ species formed from $\mathrm{SO}_{2}$ and $\mathrm{SO}_{3}$, and the interaction energies of $\mathrm{SO}_{2}$ and $\mathrm{SO}_{3}$ with the respective $\mathrm{Cu}(\mathrm{I})$ and $\mathrm{Cu}(\mathrm{II})$ species is similar in both $\mathrm{CHA}$ materials. This indicates that the framework chemistry of the two $\mathrm{Cu}$-CHA catalysts does not affect the $\mathrm{SO}_{2}$-poisoning, and means that $\mathrm{SO}_{2}$ poisoning is similar on $\mathrm{Cu}$-exchanged aluminosilicate and silicoaluminophosphate $\mathrm{CHA}$ materials.

\section{Conclusions}

The deactivation behavior of a Cu-SAPO-34 catalyst in the $\mathrm{NH}_{3}-\mathrm{SCR}$ reaction has been evaluated at simulated operating conditions by comparing the SCR activity before and after exposing to $1.5 \mathrm{ppmv} \mathrm{SO}_{2}$ in a typical SCR-feed gas feed at $300{ }^{\circ} \mathrm{C}$. The low-temperature activity is significantly lowered by the $\mathrm{SO}_{2}$ exposure, and regeneration at $550{ }^{\circ} \mathrm{C}$ restores the activity to about $80 \%$ of the original level. Regeneration at $700{ }^{\circ} \mathrm{C}$ restores all activity, which is consistent with decomposition of $\mathrm{Cu}$-sulfates. The degree of deactivation appears to depend on the total $\mathrm{SO}_{2}$ exposure, calculated as the product of partial pressure and exposure time.

Below $400{ }^{\circ} \mathrm{C}$, the S-uptake increases with temperature in absence of $\mathrm{NO}$ and $\mathrm{NH}_{3}$, and decreases with increasing temperature in the presence of $\mathrm{NO}$ and $\mathrm{NH}_{3}$. This can be explained by the ability of $\mathrm{NO}$ and $\mathrm{NH}_{3}$ to 
reduce $\mathrm{Cu}(\mathrm{II})$ to $\mathrm{Cu}(\mathrm{I})$. DFT calculations show that $\mathrm{SO}_{2}$ binds preferably to $\mathrm{Cu}(\mathrm{I})$, while $\mathrm{SO}_{3}$ binds stronger to $\mathrm{Cu}$ (II). This then leads to the higher uptake of $\mathrm{SO}_{2}$ below $400{ }^{\circ} \mathrm{C}$ in the presence of $\mathrm{NO}$ and $\mathrm{NH}_{3}$, since a larger amount of $\mathrm{Cu}(\mathrm{I})$ is present under these conditions. Above $400{ }^{\circ} \mathrm{C}$, the S-uptake decreases with increasing temperature, independent of the presence of $\mathrm{NO}$ and $\mathrm{NH}_{3}$.

The $\mathrm{S} / \mathrm{Cu}$ ratios are always lower than 1 , which indicates that the uptake of sulfur is related to adsorption of $\mathrm{SO}_{2}$ on $\mathrm{Cu}$ and that ammonium sulfate does not precipitate in the catalyst when co-feeding $\mathrm{SO}_{2}, \mathrm{H}_{2} \mathrm{O}$ and $\mathrm{NH}_{3}$. Furthermore, DFT calculations also show that $\mathrm{SO}_{2}$ and $\mathrm{SO}_{3}$ interactions with $\mathrm{Cu}$ is similar for $\mathrm{Cu}-\mathrm{SAPO}-34$ and $\mathrm{Cu}-\mathrm{SSZ}-13$, indicating that the deactivation by $\mathrm{SO}_{\mathrm{x}}$ is mainly associated to the chemistry of the $\mathrm{Cu}$ sites. Consequently, the $\mathrm{SO}_{2}$-poisoning mechanisms for $\mathrm{Cu}-\mathrm{SAPO}-34$ and $\mathrm{Cu}-\mathrm{SSZ}-13$ are comparable.

\section{Acknowledgements}

PSH gratefully acknowledges support from Innovation Fund Denmark [grant number 5139-0023B].

\section{References}

[1] J.H. Kwak, D. Tran, S.D. Burton, J. Szanyi, J.H. Lee, C.H.F. Peden, Effects of hydrothermal aging on NH3-SCR reaction over Cu/zeolites, J. Catal. 287 (2012) 203-209.

[2] I. Nova, E. Tronconi, Urea-SCR Technology for deNOx After Treatment of Diesel Exhausts, 1st ed., Springer-Verlag, New York, 2014.

[3] H.-Y. Chen, Z. Wei, M. Kollar, F. Gao, Y. Wang, J. Szanyi, C.H.F. Peden, A comparative study of $\mathrm{N} 2 \mathrm{O}$ formation during the selective catalytic reduction of $\mathrm{NOx}$ with $\mathrm{NH} 3$ on zeolite supported $\mathrm{Cu}$ catalysts, J. Catal. 329 (2015) 490-498. doi:10.1016/j.jcat.2015.06.016.

[4] Y. Cheng, C. Lambert, D.H. Kim, J.H. Kwak, S.J. Cho, C.H.F. Peden, The different impacts of SO2 and SO3 on Cu/zeolite SCR catalysts, Catal. Today. 151 (2010) 266-270.

[5] A. Kumar, M.A. Smith, K. Kamasamudram, N.W. Currier, H. An, A. Yezerets, Impact of different 
forms of feed sulfur on small-pore Cu-zeolite SCR catalyst, Catal. Today. 231 (2014) 75-82.

[6] Y. Cheng, C. Montreuil, G. Cavataio, C. Lambert, Sulfur Tolerance and DeSOx Studies on Diesel SCR Catalysts, SAE Int. J. Fuels Lubr. 1 (2008) 471-476.

[7] K. Wijayanti, S. Andonova, A. Kumar, J. Li, K. Kamasamudram, N.W. Currier, A. Yezerets, L. Olsson, Impact of sulfur oxide on NH3-SCR over Cu-SAPO-34, Appl. Catal. B. 166-167 (2015) 568-579. doi:10.1016/j.apcatb.2014.11.043.

[8] A. Kumar, M.A. Smith, K. Kamasamudram, N.W. Currier, A. Yezerets, Chemical deSOx: An effective way to recover Cu-zeolite SCR catalysts from sulfur poisoning, Catal. Today. 267 (2016) 10-16. doi:10.1016/j.cattod.2016.01.033.

[9] J. Luo, D. Wang, A. Kumar, J. Li, K. Kamasamudram, N. Currier, A. Yezerets, Identification of two types of $\mathrm{Cu}$ sites in $\mathrm{Cu} / \mathrm{SSZ}-13$ and their unique responses to hydrothermal aging and sulfur poisoning, Catal. Today. 267 (2016) 3-9. doi:10.1016/j.cattod.2015.12.002.

[10] L. Zhang, D. Wang, Y. Liu, K. Kamasamudram, J. Li, W. Epling, SO2 poisoning impact on the NH3SCR reaction over a commercial Cu-SAPO-34 SCR catalyst, Appl. Catal. B. 156-157 (2014) 371-377. doi:10.1016/j.apcatb.2014.03.030.

[11] P.S. Hammershøi, Y. Jangjou, W.S. Epling, A.D. Jensen, T.V.W. Janssens, Reversible and irreversible deactivation of Cu-CHA NH3-SCR catalysts by SO2 and SO3, Appl. Catal. B. 226 (2018) 38-45. doi:10.1016/j.apcatb.2017.12.018.

[12] K.C. Hass, W.F. Schneider, Density functional studies of adsorbates in Cu-exchanged zeolites: model comparisons and SOx binding, Phys. Chem. Chem. Phys. 1 (1999) 639-648.

[13] W. Su, Z. Li, Y. Zhang, C. Meng, J. Li, Identification of sulfate species and their influence on SCR performance of $\mathrm{Cu} / \mathrm{CHA}$ catalyst, Catal. Sci. Technol. 7 (2017) 1523-1528. doi:10.1039/C7CY00302A. 
[14] K. Wijayanti, K. Leistner, S. Chand, A. Kumar, K. Kamasamudram, N.W. Currier, A. Yezerets, L. Olsson, Deactivation of Cu-SSZ-13 by SO2 exposure under SCR conditions, Catal. Sci. Technol. 6 (2016) 2565-2579. doi:10.1039/C5CY01288K.

[15] K. Wijayanti, K. Xie, A. Kumar, K. Kamasamudram, L. Olsson, Effect of gas compositions on SO2 poisoning over Cu/SSZ-13 used for NH3-SCR, Appl. Catal. B. 219 (2017) 142-154. doi:10.1016/j.apcatb.2017.07.017.

[16] Y. Jangjou, D. Wang, A. Kumar, J. Li, W.S. Epling, SO2 Poisoning of the NH3-SCR Reaction over Cu-SAPO-34: Effect of Ammonium Sulfate versus Other S-Containing Species, ACS Catal. 6 (2016) 6612-6622. doi:10.1021/acscatal.6b01656.

[17] J.J. Mortensen, L.B. Hansen, K.W. Jacobsen, Real-space grid implementation of the projector augmented wave method, Phys. Rev. B. 71 (2005) 35109. doi:10.1103/PhysRevB.71.035109.

[18] J. Enkovaara, C. Rostgaard, J.J. Mortensen, J. Chen, M. Dulak, L. Ferrighi, J. Gavnholt, C. Glinsvad, V. Haikola, H.A. Hansen, H.H. Kristoffersen, M. Kuisma, A.H. Larsen, L. Lehtovaara, M. Ljungberg, O. Lopez-Acevedo, P.G. Moses, J. Ojanen, T. Olsen, V. Petzold, N.A. Romero, J. Stausholm-Møller, M. Strange, G.A. Tritsaris, M. Vanin, M. Walter, B. Hammer, H. Häkkinen, G.K.H. Madsen, R.M. Nieminen, J.K. Nørskov, M. Puska, T.T. Rantala, J. Schiøtz, K.S. Thygesen, K.W. Jacobsen, Electronic structure calculations with GPAW: a real-space implementation of the projector augmented-wave method, J. Phys. Condens. Matter. 22 (2010) 253202. doi:10.1088/0953-8984/22/25/253202.

[19] J. Wellendorff, K.T. Lundgaard, A. Møgelhøj, V. Petzold, D.D. Landis, J.K. Nørskov, T. Bligaard, K.W. Jacobsen, Density functionals for surface science: Exchange-correlation model development with Bayesian error estimation, Phys. Rev. B. 85 (2012) 235149. doi:10.1103/PhysRevB.85.235149.

[20] R.Y. Brogaard, P.G. Moses, J.K. Nørskov, Modeling van der Waals Interactions in Zeolites with Periodic DFT: Physisorption of n-Alkanes in ZSM-22, Catal. Lett. 142 (2012) 1057-1060. doi:10.1007/s10562-012-0870-9. 
[21] R.Y. Brogaard, B.M. Weckhuysen, J.K. Nørskov, Guest-host interactions of arenes in H-ZSM-5 and their impact on methanol-to-hydrocarbons deactivation processes, J. Catal. 300 (2013) 235-241. doi:10.1016/j.jcat.2013.01.009.

[22] T.V.W. Janssens, H. Falsig, L.F. Lundegaard, P.N.R. Vennestrøm, S.B. Rasmussen, P.G. Moses, F. Giordanino, E. Borfecchia, K.A. Lomachenko, C. Lamberti, S. Bordiga, A. Godiksen, S. Mossin, P. Beato, A Consistent Reaction Scheme for the Selective Catalytic Reduction of Nitrogen Oxides with Ammonia, ACS Catal. 5 (2015) 2832-2845. doi:10.1021/cs501673g.

[23] C. Paolucci, A.A. Verma, S.A. Bates, V.F. Kispersky, J.T. Miller, R. Gounder, W.N. Delgass, F.H. Ribeiro, W.F. Schneider, Isolation of the Copper Redox Steps in the Standard Selective Catalytic Reduction on Cu-SSZ-13, Angew. Chem. Int. Ed. 53 (2014) 1-7.

[24] F. Giordanino, P.N.R. Vennestrøm, L.F. Lundegaard, F.N. Stappen, S. Mossin, P. Beato, S. Bordiga, C. Lamberti, Characterization of Cu-exchanged SSZ-13: a comparative FTIR, UV-Vis, and EPR study with Cu-ZSM-5 and Cu- $\beta$ with similar Si/Al and Cu/Al ratios., Dalt. Trans. 42 (2013) 12741-12761.

[25] J.-S. McEwen, T. Anggara, W.F. Schneider, V.F. Kispersky, J.T. Miller, W.N. Delgass, F.H. Ribeiro, Integrated operando X-ray absorption and DFT characterization of $\mathrm{Cu}-\mathrm{SSZ}-13$ exchange sites during the selective catalytic reduction of NOx with NH3, Catal. Today. 184 (2012) 129-144.

[26] S. Kieger, G. Delahay, B. Coq, B. Neveu, Selective Catalytic Reduction of Nitric Oxide by Ammonia over Cu-FAU Catalysts in Oxygen-Rich Atmosphere, 183 (1999) 267-280.

[27] F. Gao, D. Mei, Y. Wang, J. Szanyi, C.H.F. Peden, Selective Catalytic Reduction over Cu/SSZ-13: Linking Homo- and Heterogeneous Catalysis, J. Am. Chem. Soc. 139 (2017) 4935-4942. doi:10.1021/jacs.7b01128.

[28] C. Paolucci, I. Khurana, A.A. Parekh, S. Li, A.J. Shih, H. Li, J.R. Di Iorio, J.D. Albarracin-Caballero, A. Yezerets, J.T. Miller, W.N. Delgass, F.H. Ribeiro, W.F. Schneider, R. Gounder, Dynamic multinuclear sites formed by mobilized copper ions in NO x selective catalytic reduction, Science, 357 
(2017) 898-903. doi:10.1126/science.aan5630. 